\title{
Plant species and growing season weather influence the efficiency of selenium biofortification
}

\author{
Nashmin Ebrahimi (iD · Frederick L. Stoddard • Helinä Hartikainen • \\ Mervi M. Seppänen
}

Received: 9 January 2019/Accepted: 1 April 2019/Published online: 6 April 2019

(C) The Author(s) 2019

\begin{abstract}
Se deficiency is widespread in agricultural soils; hence, agronomic Se biofortification is an important strategy to overcome its deficiency in humans and animals. In Finland, fertilizers have been amended with inorganic Se for over 20 years to reverse the negative effects of low Se content in feed and food. Plant species, climatic conditions, other nutrients and soil properties affect the efficiency of Se biofortification. The present two years' study compared the ability of oilseed rape, wheat and forage grasses to uptake fertilizer $\mathrm{Se}$ applied as sodium selenate in a sub-boreal environment. The effect of foliar $\mathrm{N}$ application on $\mathrm{Se}$ uptake was tested in
\end{abstract}

N. Ebrahimi $(\bowtie) \cdot$ M. M. Seppänen

Department of Agricultural Sciences, University of

Helsinki, P.O. Box 27, Latokartanonkaari 5-7,

00014 Helsinki, Finland

e-mail: nashmin.ebrahimi@helsinki.fi

M. M. Seppänen

e-mail: mervi.seppanen@helsinki.fi

F. L. Stoddard

Department of Agricultural Sciences, Viikki Plant Science Centre and Helsinki Sustainability Centre, University of Helsinki, P.O. Box 27, Latokartanonkaari 5-7,

00014 Helsinki, Finland

e-mail: frederick.stoddard@helsinki.fi

H. Hartikainen

Department of Food and Environmental Sciences,

University of Helsinki, P.O. Box 27, Latokartanonkaari

11, 00014 Helsinki, Finland

e-mail: helina.hartikainen@helsinki.fi the second year. Se concentration was determined in plant parts and in soil samples taken at the end of growth season in both years as well as from another plot where Se fertilizer had been used for 20 years. Se fertilizer recovery in harvested wheat and oilseed rape was $1-16 \%$, and in forage grasses was $52-64 \%$ in the first harvest and 15-19\% in the second harvest. Foliar $\mathrm{N}$ application improved Se uptake only at the higher Se fertilizer level. The efficiency of biofortification depended on weather conditions, with forage grasses being the most reliable crop. Oilseed rape as a Se semiaccumulator had no advantage in Se biofortification in field conditions due to low translocation to seeds.

Keywords Se uptake efficiency $(\mathrm{SeUP}) \cdot \mathrm{Se}$ fertilizer recovery $(\mathrm{SeFR}) \cdot$ Se cycling $\cdot$ Forage grasses $\cdot$ Oilseed rape $\cdot$ Wheat

\section{Introduction}

Selenium (Se) has been identified as an essential trace element for humans and animals because of its functions in selenoproteins, including glutathione peroxidase and thioredoxin reductase (Brown and Arthur 2001; Rayman 2002). The Se content in soils ranges from $<0.1 \mathrm{mg} \mathrm{kg}^{-1}$ in Finnish podzols to more than $80 \mathrm{mg} \mathrm{kg}^{-1}$ in the seleniferous soils of the western United States (Gupta and Gupta 2000; Hartikainen 2005), and the Se content of food and feed 
produced in these areas varies accordingly. The lowest Se concentration in cereals from countries belonging to the Food and Agricultural Organization (FAO) was from Finland, $0.008 \mathrm{mg} \mathrm{kg}^{-1} \mathrm{DM}$ (Sillanpää and Jansson 1992). In 1984, Finnish authorities decided to improve the Se concentration of food and feed by adding $\mathrm{Na}_{2} \mathrm{SeO}_{4}$ to synthetic fertilizers (Eurola et al. 1990). Since 2012, Se has been applied to soil at $10 \mathrm{mg} \mathrm{ha}^{-1}$ and the daily Se intake by Finnish people is now at the optimal level of 70-80 $\mu \mathrm{g}$ (Alfthan et al. 2015). Similarly, agronomic Se biofortification of pasture and forage crops has improved Se intake in livestock (Gupta et al. 1982; Yläranta 1984; Whelan 1989; Gupta and Gupta 2002). Se-enriched fertilizers are now used in several countries such as Australia, New Zealand, the UK and Malawi (Wichtel 1998; Lee et al. 1999; Fordyce 2013; Broadley et al. 2006).

Less than $30 \%$ of total applied Se is accumulated in harvested crop parts and in the case of seed crops the recovery is even lower (Eich-Greatorex et al. 2007; Broadley et al. 2010; Stavridou et al. 2012; Ebrahimi et al. 2018). Yläranta (1985) reported that only 5-20\% of added selenate is removed in harvested grain, and that the rest is probably retained in soil in insoluble forms, volatilized by plants or soil microorganisms, or lost by leaching. There are two main bottlenecks in Se biofortification, the first being the low bioavailability of Se in soil and especially the slow degradation of Secontaining plant residues, and the second being the limited translocation of Se to seeds (Ebrahimi et al. 2018).

Analysis of the fate of applied fertilizer Se in the field ecosystem is challenging. In their 25-year followup study with selenate, Eurola et al. (2008) found no change in hot-water extractable soil Se concentration). In contrast, long-term (1992 to 2004) selenate application to mineral soil is reported to have elevated the Se concentration in adsorbed, organically associated and recalcitrant (organic $\mathrm{Se}$ or metal selenides extracted by $\mathrm{NaOCl}$ ) fractions by 5,15 and $9 \mu \mathrm{g} \mathrm{kg}^{-1}$, respectively (Keskinen et al. 2011). This outcome supports Yläranta's (1985) assumption that residual Se accumulates in soil in an insoluble form. Keskinen et al. (2013) reported that, depending on the Se dosage and the peat content of soil, $15-80 \%$ of added Se was recovered in the $\mathrm{NH}_{4} \mathrm{Cl}$-extraction, whereas only $5-15 \%$ was extracted by phosphate buffer solution. These results are consistent with earlier studies (Yläranta 1983a, b; Keskinen et al. 2010). These salt-soluble (phosphate buffer) Se forms may leach easily.

A meta-analysis of 243 studies (Ros et al. 2016) revealed that selenate was the most efficient species of $\mathrm{Se}$ and that foliar was the most efficient method. Nevertheless, even then only $10 \%$ of the applied Se was taken up by the plants (Ros et al. 2016). Selenate is easily leached to deeper layers in the soil profile (Stroud et al. 2010). Soil organic matter content and the total Se concentration in the soil only slightly affect Se uptake. Other agroecosystem factors such as climate and the content of bioavailable $\mathrm{Se}$ are of greater importance when optimizing the fertilization strategies (Ros et al. 2016).

Volatilization is an important mechanism of Se loss. Plant species, microbial activity (Zayed and Terry 1994), soil characteristics and weather conditions (Frankenberger and Karlson 1994; Lin et al. 1999) all affect the rate of volatilization. It is reported to range from as low as $3 \mu \mathrm{g} \mathrm{m}^{-2} \mathrm{day}^{-1}$ in soils containing 3-8.2 $\mathrm{mg} \mathrm{Se} \mathrm{kg}^{-1}$ (Banuelos et al. 2005), to as high much as $1300 \mu \mathrm{g} \mathrm{m}^{-2}$ day $^{-1}$ in soils with $11 \mathrm{mg} \mathrm{Se} \mathrm{kg}{ }^{-1}$ (Frankenberger and Karlson 1995).

Chemical and physical properties of Se and $\mathrm{S}$ are similar. Other nutrients such as $\mathrm{N}$ can affect the uptake, translocation and remobilization of $\mathrm{Se}$, but there are few studies on Se and $\mathrm{N}$ interaction in plants. Combined application of $\mathrm{N}$ and $\mathrm{Se}$ is reported to improve the growth of potato more than each nutrient applied alone (Yassen et al. 2011). The negative effect of continuous application of mineral $\mathrm{N}$ on the $\mathrm{Se}$ concentration in vegetables has been attributed to the accumulation of nitrate in soil, leading to competition with Se for uptake by plants (Li et al. 2015). Similarly, Klikocka et al. (2017) reported that $\mathrm{N}$ applications of 40 and $80 \mathrm{~kg} \mathrm{ha}^{-1}$ increased the Se content of wheat grain, but when $\mathrm{N}$ dosage was $120 \mathrm{~kg} \mathrm{ha}^{-1}$, no significant effect on the Se content of grain was observed.

The present study was undertaken to (1) compare the ability of different crops to take up fertilizer Se, (2) test the effects of $\mathrm{N}$ application on Se uptake, and (3) explore the fate of fertilizer $\mathrm{Se}$ in the field. By combining the data of a short-term and a long-term experiment, we aimed (4) to develop a model of the Se cycle in a sub-boreal field agroecosystem where fertilizers are the main source of the nutrients. 


\section{Materials and methods}

Field experiments

A 2-year field experiment (2011 and 2012) on wheat (Triticum aestivum L. emend Thell. cv. 'Marble') and oilseed rape (Brassica napus L. ssp. oleifera Metzg. cv. 'Belinda') and a 1-year experiment (2012) on silage grass (a mixture of timothy grass (Phleum pratense L.) and red clover (Trifolium pratense L.)) with four replications were conducted at the Kotkaniemi experimental station (Yara Suomi Ltd.) in southern Finland $\left(60^{\circ} 21^{\prime} \mathrm{N}, 24^{\circ} 22^{\prime} \mathrm{E}\right)$. Soil properties of the experimental fields and weather conditions are given in Table 1 and Fig. 1, respectively. Both wheat and oilseed rape were cultivated at three levels of $\mathrm{Se}$ (0, 7.22 and $25 \mathrm{~g} \mathrm{ha}^{-1}$ as $\left.\mathrm{Na}_{2} \mathrm{SeO}_{4}\right)$ applied in Seenriched fertilizer at sowing time. The Se concentrations in the fertilizers were 0,15 and $50 \mathrm{mg} \mathrm{kg}^{-1}$. In all treatments the $\mathrm{N}$ added in the fertilizer (YaraBela Suomensalpietari 27-0-1, Yara Suomi Ltd., Vihti, Finland) was $130 \mathrm{~kg} \mathrm{ha}^{-1}$. In 2012, at bolting stage the plants received an additional foliar $\mathrm{N}$ dosage $\left(20 \mathrm{~kg} \mathrm{ha}^{-1}\right)$.

Furthermore, $\mathrm{Na}_{2} \mathrm{SeO}_{4}$ was used for silage grasses to obtain Se additions of at $0,5.55$ and $19.25 \mathrm{~kg} \mathrm{ha}^{-1}$ and, the $\mathrm{N}$ dosage for the first and second harvests was $100 \mathrm{~kg} \mathrm{ha}^{-1}$. To study the impact of long-term application of Se on its concentration in soil, samples of the topsoil $(0.00-0.05 \mathrm{~m})$ and subsoil $(0.30 \mathrm{~m})$ were collected from a field fertilized for 20 years (1984-2014) with Se-NPK fertilizer (0, 80 and $160 \mathrm{~kg} \mathrm{ha}^{-1}$ ) and the Se concentration was determined. The amounts of Se applied in the $80 \mathrm{~kg} \mathrm{ha}^{-1}$
NPK were 5.6 (1984-1989), 2.1 (1990-1997), 3.5 (1998-2006) and $5.25 \mathrm{~g} \mathrm{ha}^{-1}$ (2007-2014) and double these amounts in the $160 \mathrm{~kg} \mathrm{ha}^{-1} \mathrm{NPK}$ application.

Plant sampling and harvesting

In 2011, wheat and oilseed rape samples were harvested at four developmental stages (I: tillering/ rosette, II: stem elongation/inflorescence emergence, III: heading/flowering and IV: mature seeds) and in 2012 at three stages (I: tillering/rosette, II: heading/ flowering and III: mature seeds). The plant material samples were fractioned into roots, leaves, stems, flowers, siliques/chaff and seeds/grains and dried at $70{ }^{\circ} \mathrm{C}$ overnight. The dry matter of each fraction was weighed and the Se concentration in each fraction was separately determined. Silage grass samples were taken on 15 June (I) and 16 August (II) when the crops were harvested, and the aboveground plant material was separated into timothy and red clover fractions. Root samples collected from the silage plots were carefully washed and dried for analysis.

Plant Se analysis

The method used to analyze Se in plant samples has been described previously (Ebrahimi et al. 2015). Briefly, $0.4-0.8 \mathrm{~g}$ of ground plant material was digested overnight in an acid mixture $\left(\mathrm{HNO}_{3}: \mathrm{H}_{2} \mathrm{SO}_{4}\right.$ : $\left.\mathrm{HClO}_{4}, 6: 2: 3\right)$. Thereafter, Se (VI) was reduced to Se (IV) by adding $12 \% \mathrm{HCl}$ and by heating the samples for $20 \mathrm{~min}$ at $130{ }^{\circ} \mathrm{C}$. The volume of samples was adjusted with distilled water to $25 \mathrm{ml}$ (controls and

Table 1 Soil $\mathrm{pH}$ and total concentrations of $\mathrm{Ca}, \mathrm{P}, \mathrm{K}, \mathrm{Mg}, \mathrm{S}, \mathrm{B}, \mathrm{Cu}, \mathrm{Mn}$ and $\mathrm{Zn}\left(\mathrm{mg} \mathrm{kg}^{-1}\right)$ in the topsoil of the experimental field plots in southern Finland

\begin{tabular}{|c|c|c|c|c|c|c|c|c|c|c|c|}
\hline Year & Crops & $\mathrm{pH}^{\mathrm{a}}$ & $\mathrm{Ca}$ & $\mathrm{P}$ & $\mathrm{K}$ & $\mathrm{Mg}$ & S & B & $\mathrm{Cu}$ & Mn & $\mathrm{Zn}$ \\
\hline \multirow[t]{3}{*}{2011} & Grass-clover & 6.2 & 1840 & 8.1 & 211 & 97 & 12.3 & $\mathrm{~nm}$ & 1.8 & 12 & 1.14 \\
\hline & Oilseed rape & 5.7 & 1400 & 19 & 150 & 160 & 9.4 & 0.7 & 3.5 & 59 & 3.46 \\
\hline & Wheat & 5.6 & 1500 & 19 & 170 & 160 & 10.5 & 0.9 & 3.9 & 100 & 4.98 \\
\hline \multirow[t]{3}{*}{2012} & Grass-clover & 6.4 & 4100 & 13 & 180 & 710 & 12.2 & 0.8 & 6.6 & 17 & 1.87 \\
\hline & Oilseed rape & 6.5 & 3400 & 9.2 & 160 & 590 & 10.6 & 1.0 & 6.1 & 24 & 2.19 \\
\hline & Wheat & 6.4 & 3100 & 8.0 & 170 & 560 & 11.5 & 0.7 & 6.5 & 33 & 2.55 \\
\hline
\end{tabular}

$\mathrm{nm}$ not measured

${ }^{\mathrm{a}} \mathrm{pH}$ was measured by $0.01 \mathrm{M} \mathrm{CaCl}_{2}$ 
Fig. 1 Daily mean temperature $\left({ }^{\circ} \mathrm{C}\right)$ and precipitation ( $\mathrm{mm}$ ) from May to September of a 2011 and $\mathbf{b} 2012$ in the fields (a) 2011

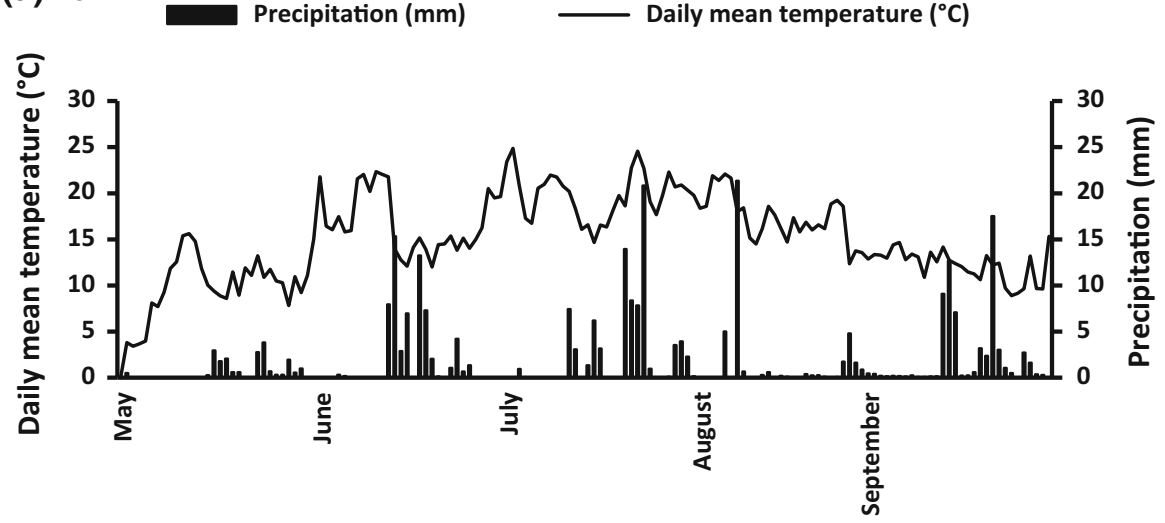

(b) $2012 \square$ Precipitation (mm)

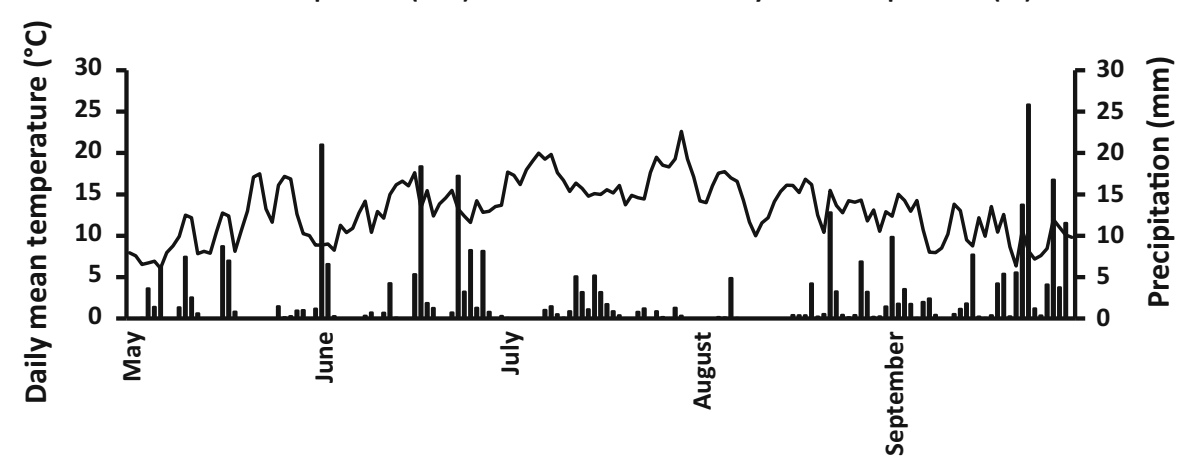

low Se treatments) or $50 \mathrm{ml}$ (high Se treatment) and the subsamples were analyzed by inductively coupled plasma-optical emission spectroscopy (ICP-OES) (iCPA 6000 Series, Thermo Scientific, Vantaa, Finland). The standard curve prepared from $\mathrm{Na}_{2} \mathrm{SeO}_{4}$ solution (Merck or Sigma Aldrich with $\geq 98 \%$ purity) covered Se concentrations from 0 to $500 \mu \mathrm{g} \mathrm{l}^{-1}$. Wheat flour with a known Se concentration was used as an internal standard (Ebrahimi et al. 2015). Owing to limited resources, only three of the four field replicates were analyzed.

Soil Se analysis

To separate the inorganic and organically associated Se pools in soil, a sequential extraction procedure (SEP2) (Keskinen 2012) was used, but with only two extraction buffers instead of five. Soil samples were air-dried at $40{ }^{\circ} \mathrm{C}$ overnight and passed through a $2 \mathrm{~mm}$ sieve to remove stones and plant residues. For extraction of inorganic soluble Se and Se adsorbed onto the surfaces of $\mathrm{Al}$ and Fe oxides, $10 \mathrm{~g}$ of soil samples were suspended in $50 \mathrm{ml}$ of $0.1 \mathrm{M} \mathrm{KH}_{2} /$ $\mathrm{K}_{2} \mathrm{HPO}_{4}(\mathrm{pH} 8)$ in 100-ml plastic tubes and agitated on a reciprocating shaker at $250 \mathrm{rpm}$ for $2 \mathrm{~h}$. The suspensions were centrifuged for $10 \mathrm{~min}(3000 \times \mathrm{g})$ at room temperature and filtered through a blue-ribbon filter (Whatman Grade 589/3, $2 \mu \mathrm{m}$ ). This process was repeated, and the two filtrates were pooled and stored at $5{ }^{\circ} \mathrm{C}$ until analysis.

To extract organic Se, the pellets from the previous step were suspended in $50 \mathrm{ml}$ of $0.1 \mathrm{M} \mathrm{NaOH}$ and agitated on a reciprocal shaker for $4 \mathrm{~h}$. Thereafter, the samples were centrifuged and filtered as before, and stored at $5{ }^{\circ} \mathrm{C}$ until analysis. Samples of both inorganic and organic fractions were analyzed by ICP-OES at Metropolia Lab (Helsinki, Finland). Se concentrations in filtrates were converted to Se uptake by multiplying them by the dry matter yield. 
Parameter calculations

To compare the plant species' efficiency of $\mathrm{Se}$ fertilizer use, the following parameters were calculated:

$$
\begin{array}{ll}
\text { (A) } & \mathrm{Se} \text { uptake efficiency } \quad(\mathrm{SeUPE})=(\mathrm{Se} \\
\text { uptake } \left._{\text {in treated }}-\mathrm{Se} \mathrm{uptake}_{\text {in control }}\right) / \mathrm{Se}_{\text {applied }} \\
\text { (B) } \mathrm{Se} \mathrm{fertilizer} \mathrm{recovery}(\mathrm{SeFR})=(\mathrm{Se} \\
\text { uptake }_{\text {in treated seed or shoot }}-\mathrm{Se} \text { uptake } \mathrm{un}_{\text {in }} \text { con- } \\
\text { trol seed or shoot } / \mathrm{Se}_{\text {applied. }}
\end{array}
$$

Statistical analysis

The results of the harvests of both grain crops in the 2 years were analyzed separately, because the harvesting times differed in the growing seasons. Furthermore, data obtained in each year were classified according to the harvesting time. The variance was analyzed using one-way ANOVA, and Tukey's HSD test with $P \leq 0.05$ was used to compare the means. Multivariate analysis was performed to show the interaction between Se fertilizer levels and plant species or between Se and $\mathrm{N}$ fertilizers. The grassclover dataset was analyzed separately by one-way ANOVA and Tukey's HSD test with $P \leq 0.05$ was used to compare the means.

\section{Results}

The efficiency of Se biofortification in different plant species

Se concentration in the seeds of oilseed rape and wheat increased with increasing Se dosage and the target concentration of biofortification $\left(0.1 \mathrm{mg} \mathrm{kg}^{-1} \mathrm{DW}\right)$ was reached with the lower application (7.22 $\left.\mathrm{g} \mathrm{ha}^{-1}\right)$ in 2011 but not with either application in 2012 (Table 2). The plant species did not differ significantly in their Se concentration at any application level, nor was the Se level $\times$ plant species interaction significant (2011: $P=0.995,2012: P=0.968)$. In both plant species, the foliar $\mathrm{N}$ application in 2012 had a nonsignificant impact on the Se translocation to seeds, and no interaction between $\mathrm{Se}$ and $\mathrm{N}$ fertilizers was found $(P=0.723)$.

Timothy and red clover plants accumulated high amounts of $\mathrm{Se}$ in the harvested shoot biomass (Table 3). Especially in the first harvest of timothy, the highest Se dosage $\left(19.25 \mathrm{~g} \mathrm{ha}^{-1}\right)$ produced a $\mathrm{Se}$ concentration as high as $1.43 \mathrm{mg} \mathrm{kg}^{-1} \mathrm{DW}$. In both harvests, more Se was taken up by timothy than by red clover. Furthermore, the difference in the shoot Se concentrations between the harvests was higher in the grass than in the legume. In both forage species, the Se concentration in the shoots was high in 2012 although

\begin{tabular}{|c|c|c|c|c|}
\hline \multirow[t]{3}{*}{ Species } & \multirow[t]{3}{*}{ Se application to soil $\left(\mathrm{g} \mathrm{ha}^{-1}\right)$} & \multicolumn{3}{|c|}{ Se concentration $\left(\mathrm{mg} \mathrm{kg}^{-1} \mathrm{DW}\right)$ in seeds } \\
\hline & & \multirow{2}{*}{$\begin{array}{l}2011 \\
\text { Foliar N: } 0 \mathrm{~kg} \mathrm{ha}^{-1}\end{array}$} & \multicolumn{2}{|l|}{2012} \\
\hline & & & Foliar N: $0 \mathrm{~kg} \mathrm{ha}^{-1}$ & $20 \mathrm{~kg} \mathrm{~N} \mathrm{ha}^{-1}$ \\
\hline \multirow[t]{3}{*}{ Oilseed rape } & 0 & $0.02^{\mathrm{b}}$ & $0.03^{\mathrm{b}}$ & $0.04^{\mathrm{b}}$ \\
\hline & 7.22 & $0.22^{\mathrm{b}}$ & $0.08^{\mathrm{b}}$ & $0.05^{\mathrm{b}}$ \\
\hline & 25 & $0.89^{\mathrm{a}}$ & $0.26^{\mathrm{a}}$ & $0.28^{\mathrm{a}}$ \\
\hline \multirow[t]{3}{*}{ Wheat } & 0 & $0.03^{\mathrm{b}}$ & $0.05^{\mathrm{b}}$ & $0.06^{\mathrm{b}}$ \\
\hline & 7.22 & $0.22^{\mathrm{b}}$ & $0.07^{\mathrm{b}}$ & $0.09^{\mathrm{b}}$ \\
\hline & 25 & $0.91^{\mathrm{a}}$ & $0.26^{\mathrm{a}}$ & $0.30^{\mathrm{a}}$ \\
\hline SE & & 0.10 & 0.04 & 0.04 \\
\hline
\end{tabular}
the biofortification of wheat and oilseed rape failed in that year (Tables 2, 3).

Table 2 Selenium concentration $\left(\mathrm{mg} \mathrm{kg}^{-1} \mathrm{DW}\right)$ in the seeds of oilseed rape and wheat cultivated in 2011 and 2012 without or with $\mathrm{Se}$ added at two levels and with or without foliar $\mathrm{N}$ addition $\left(20 \mathrm{~kg} \mathrm{ha}^{-1}\right)$

Data are means, $n=3$. Values in each column followed by the same letter are not significantly different at $P \leq 0.05$ by Tukey's HSD test 
Table 3 Selenium concentration $\left(\mathrm{mg} \mathrm{kg}^{-1} \mathrm{DW}\right)$ in the shoots of timothy and red clover at two harvests following three Se treatments in 2012

\begin{tabular}{llll}
\hline Species & Se application to soil $\left(\mathrm{g} \mathrm{ha}^{-1}\right)$ & \multicolumn{2}{l}{ Se concentration $\left(\mathrm{mg} \mathrm{kg}^{-1} \mathrm{DW}\right)$ in shoots } \\
\cline { 3 - 4 } & & Harvest I: 15 June & $0.02^{\mathrm{d}}$ \\
\hline Timothy & 0 & $0.01^{\mathrm{c}}$ & $0.35^{\mathrm{bc}}$ \\
& 5.55 & $0.43^{\mathrm{b}}$ & $1.07^{\mathrm{a}}$ \\
& 19.25 & $1.43^{\mathrm{a}}$ & $0.05^{\mathrm{d}}$ \\
Red clover & 0 & $0.03^{\mathrm{c}}$ & $0.18^{\mathrm{cd}}$ \\
& 5.55 & $0.16^{\mathrm{bc}}$ & $0.52^{\mathrm{b}}$ \\
SE & 19.25 & $0.42^{\mathrm{b}}$ & 0.07
\end{tabular}

Data are means, $n=3$. Values in each column followed by the same letter are not significantly different at $P \leq 0.05$ by Tukey's HSD test

Selenium accumulation in plant biomass

In 2011, the Se uptake $\left(\mu \mathrm{g} \mathrm{m}^{-2}\right)$ by oilseed rape plants was significantly higher at the higher Se application level than that of wheat plants in their reproductive phase (III and IV) (Fig. 2a). A significant difference between the species was not found in 2012 (Fig. 2b). The Se uptake in oilseed rape decreased towards maturity due to the senescence of the lower leaves. There was a significant interaction between Se level and plant species in harvest IV in $2011(P=0.029)$, and both harvests II $(P=0.042)$ and III $(P=0.038)$ in 2012. However, foliar $\mathrm{N}$ application enhanced $\mathrm{Se}$ uptake at the harvest II in oilseed rape plants but had no significant effect on Se uptake in either species. There was no significant interaction between Se and $\mathrm{N}$ treatments on Se uptake, which was significantly lower in 2012 than in 2011 (Fig. 2a, b). The total Se uptake by timothy and red clover foliage was much greater than those by oilseed rape and wheat in 2012, especially in harvest I (compare Fig. 2b, c). The Se uptake at harvest II was notably lower than that at harvest I due to the combination of lower biomass with lower Se concentration (Table 3).

\section{Se translocation to seeds}

In the vegetative phase, $\mathrm{Se}$ accumulated first in the stems and leaves of oilseed rape and wheat, and its translocation to the grains during the grain-filling stage was demonstrated by the reduction of Se content in the leaves and stems and its increase in the developing reproductive organs. Oilseed rape roots took up more Se than wheat roots in 2011 (Table 4) but not in 2012 (Table 5). At maturity, 24-53\% (2011) or $42-69 \%$ (2012) of the total Se within the plants was recovered in seeds (Tables 4, 5). In 2012, the stems still contained high amounts of Se, though its proportion was significantly lower in 2011 (Table 5). A substantial proportion of Se was recovered in siliques and chaff, indicating poor translocation to seeds, especially in oilseed rape. The Se level by species interaction was significant $(P=0.001)$ for this plant part in 2011 but not in 2012. The Se accumulation increased with elevated Se application more in the wheat grains than in oilseed rape (Se level $\times$ species interaction, $P=0.001$ ). Moreover, at the higher $\mathrm{Se}$ dosage, the foliar $\mathrm{N}$ application (interaction) was associated with greater Se translocation to the seeds $(P=0.045)$.

\section{Uptake efficiency and recovery of Se fertilizer}

In 2011, the uptake efficiency (UPE) of Se was 10 times higher than in 2012, but no significant differences between the plant species or the Se applications were recorded (Table 6). In 2012, the lowest amount of UPE was related to the low-Se with foliar N application treatment in oilseed rape by $2.6 \%$ and the highest amount was recorded for the high-Se treatments without or with foliar $\mathrm{N}$ application in wheat by 7.4 and $7.9 \%$ respectively. Fertilizer recovery (FR) followed the same patterns. The UPE and FR of the grass-clover mixture were much higher than those of 

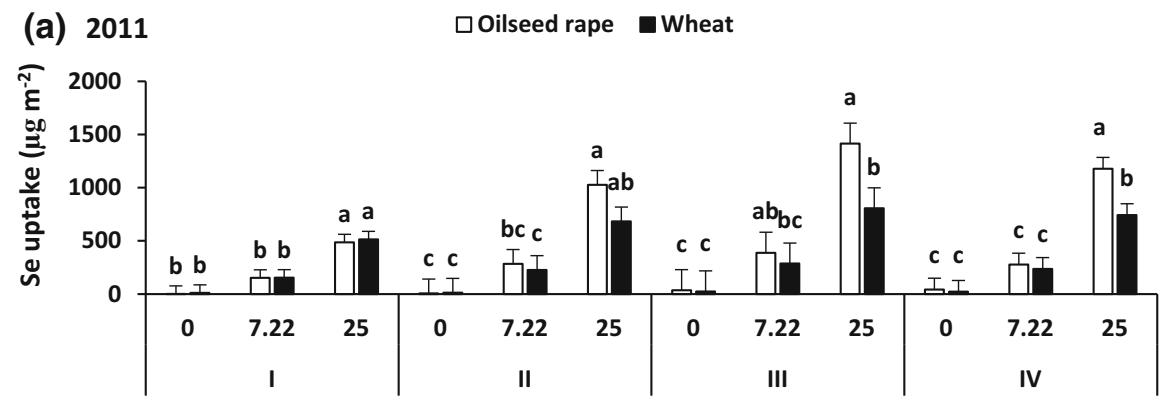

(b) 2012

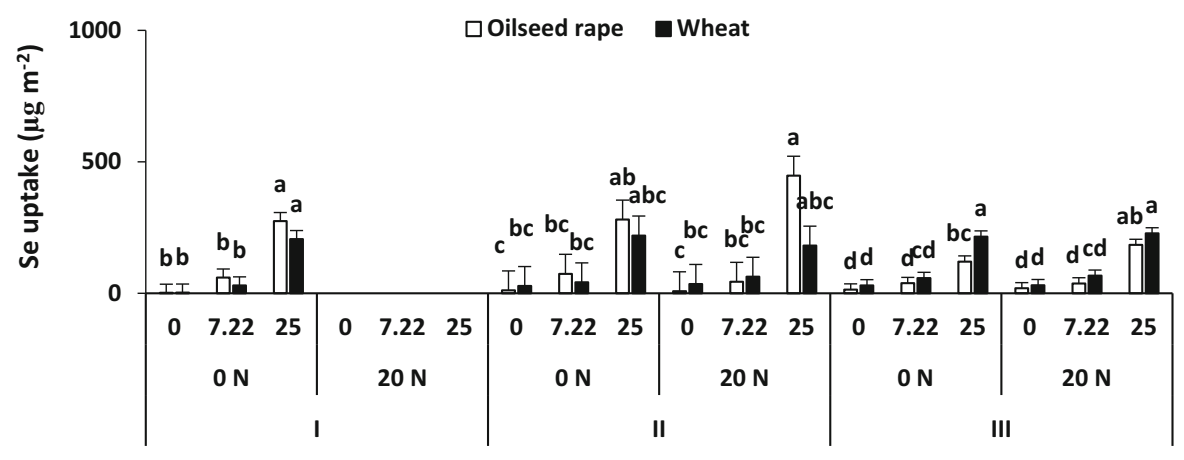

(c) 2012

Dimothy + Red clover

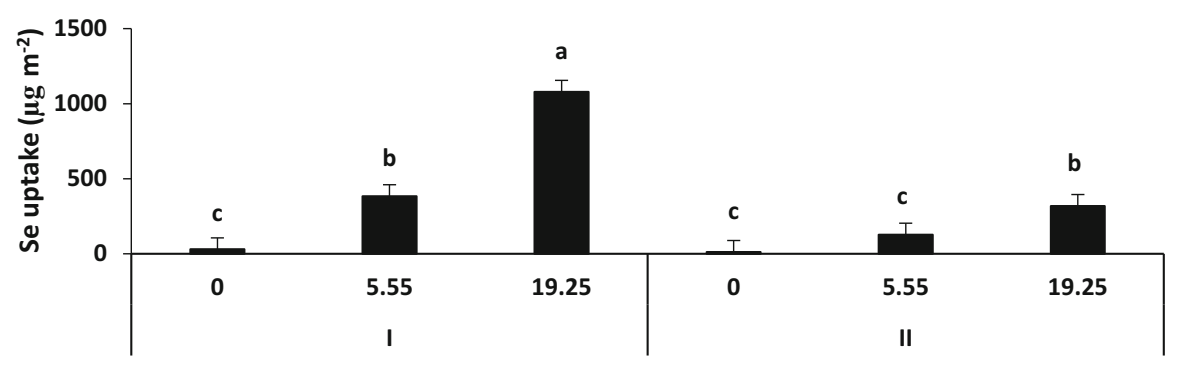

Fig. 2 Total Se uptake $\left(\mu \mathrm{g} \mathrm{m}^{-2}\right)$ in oilseed rape and wheat plants cultivated in a 2 -year field experiment at various $\mathrm{Se}$ fertilization levels and harvested at different growth stages $\mathbf{a}$ in 2011 (I-IV) and b in 2012 (I-III), and $\mathbf{c}$ in herbage biomass (timothy and red clover) harvested in 2012 on 15 June (I) and 16 August (II). The foliar $\mathrm{N}$ fertilization $\left(20 \mathrm{~kg} \mathrm{ha}^{-1}\right)$ of fertilized

oilseed rape or wheat plants in the same year (compare Tables 6, 7). In the forage crop, both UPE and FR in the harvest I were much higher than in harvest II, but they did not differ between the Se treatments (Table 7).

Soil Se status in short and long-term field experiments

Soil inorganic and organic Se concentrations were not significantly affected by the level of Se application in oilseed rape and wheat plants was applied after the first harvest. Se uptakes at different growth stages were tested separately (graphs a, b), and the data of herbage biomass in both harvests (c) were tested together, with $n=3$. Bars with the same letter do not significantly differ at $P \leq 0.05$ by Tukey's HSD test

either of the experimental years (Fig. 3a, b), but were higher in 2012 than in 2011.

Soil inorganic and organic Se concentrations were not significantly affected by the level of Se application in either of the experimental years (Fig. 3a, b), but were higher in 2012 than in 2011. In addition, in the long-term field experiment (20-year Se fertilization), the higher dosage of fertilizer $\mathrm{N}\left(160 \mathrm{~kg} \mathrm{ha}^{-1}\right)$ elevated the concentration of organic Se in the topsoil and subsoil. The concentration tended to be higher in the topsoil than in the subsoil (Fig. 3c). When the 
Table 4 Selenium uptake $\left(\mu \mathrm{g} \mathrm{m}^{-2}\right)$ in various parts of oilseed rape and wheat plants cultivated at three Se levels and harvested in 2011

\begin{tabular}{|c|c|c|c|c|c|c|c|}
\hline \multirow[t]{2}{*}{ Species } & \multirow{2}{*}{$\begin{array}{l}\text { Se application } \\
\left(\mathrm{g} \mathrm{ha}^{-1}\right)\end{array}$} & \multicolumn{6}{|c|}{ Se uptake $\left(\mu \mathrm{g} \mathrm{m}^{-2}\right)$} \\
\hline & & Root & Stem & Leaves & $\begin{array}{l}\text { Senescing } \\
\text { leaves }\end{array}$ & Seed & Siliques/chaff \\
\hline \multirow[t]{3}{*}{ Oilseed rape } & 0 & $1.5^{\mathrm{b}}(0.04)$ & $12.5^{\mathrm{c}}(0.30)$ & $0.8^{\mathrm{b}}(0.02)$ & $*$ & $10.2^{\mathrm{b}}(0.24)$ & $17.4^{\mathrm{b}}(0.40)$ \\
\hline & 7.22 & $21.2^{\mathrm{ab}}(0.07)$ & $86.0^{\mathrm{bc}}(0.31)$ & $1.8^{\mathrm{b}}(0.01)$ & $*$ & $89.1^{\mathrm{b}}(0.32)$ & $78.7^{\mathrm{b}}(0.29)$ \\
\hline & 25 & $55.4^{\mathrm{a}}(0.05)$ & $321.3^{\mathrm{a}}(0.27)$ & $11.8^{\mathrm{a}}(0.01)$ & $*$ & $354.1^{\mathrm{a}}(0.30)$ & $439.5^{\mathrm{a}}(0.37)$ \\
\hline \multirow[t]{3}{*}{ Wheat } & 0 & $1.7^{\mathrm{b}}(0.08)$ & $9.3^{\mathrm{c}}(0.42)$ & $*$ & $2.3^{\mathrm{a}}(0.11)$ & $7.7^{\mathrm{b}}(0.35)$ & $0.9^{\mathrm{b}}(0.04)$ \\
\hline & 7.22 & $4.6^{\mathrm{b}}(0.02)$ & $76.9^{\mathrm{bc}}(0.32)$ & $*$ & $25.2^{\mathrm{a}}(0.11)$ & $93.7^{\mathrm{b}}(0.39)$ & $36.4^{\mathrm{b}}(0.16)$ \\
\hline & 25 & $6.8^{\mathrm{ab}}(0.01)$ & $183.4^{\mathrm{b}}(0.25)$ & $*$ & $52.6^{\mathrm{a}}(0.07)$ & $398.7^{\mathrm{a}}(0.53)$ & $100.8^{\mathrm{b}}(0.14)$ \\
\hline SE & & 14.9 & 37.4 & 2.4 & 16.5 & 61.7 & 48.4 \\
\hline
\end{tabular}

Numbers within brackets show the proportion of Se accumulated in the biomass of each plant part per $\mathrm{m}^{2}$

Data are means, $n=3$. Values in each column followed by the same letter are not significantly different at $P \leq 0.05$ by Tukey's HSD test

*no samples for measurement

recommended amount of fertilizer was used ( $\mathrm{N}$ at $80 \mathrm{~kg} \mathrm{ha}^{-1}$ ), no Se accumulation in topsoil was observed.

\section{Discussion}

In the present study, SeUPE and SeFR varied between the crops, with SeFR being much higher in the forage grasses than in wheat or oilseed rape. In 2011, the translocation of Se to the seeds limited SeFR especially in oilseed rape with its high SeUPE. These results are in accordance with the previous greenhouse experiments revealing that the bottleneck in Se biofortification of oilseed rape is its poor loading from the silique walls to seeds (Ebrahimi et al. 2018). Palmgren et al. (2008) reported that in cereals, the bottleneck in $\mathrm{Fe}$ and $\mathrm{Zn}$ biofortification is the phloem unloading to seeds. Interestingly, wheat had a lower SeUPE than oilseed rape, but it was more efficient in the translocation of absorbed Se to the grains.

Plant species differ in their ability to take up and assimilate Se (Terry et al. 2000). Differences in root morphology and biochemical or physiological pathways are associated with different rates of uptake (Berkelaar and Hale 2000; Harskamp et al. 2010). The sulphur (S)-rich Brassica species tend to accumulate higher concentrations of Se than other species due to the biosynthesis of glucosinolate (Bañuelos et al.
2007; Harskamp et al. 2010) and this may explain the SeUPE being higher in oilseed rape than in wheat in the present study. Oilseed rape has low $\mathrm{N}$ use efficiency, mainly due to low $\mathrm{N}$ remobilization during plant senescence. Avice and Etienne (2014) reported that only $50 \%$ of absorbed $\mathrm{N}$ was harvested in the seeds, whereas high levels of residual $\mathrm{N}$ remained in fallen leaves. In this study, approximately $1-3 \%$ and $29-40 \%$ of the absorbed Se remained in senescing leaves and siliques, respectively. Thus, the reason for the poor SeFR seemed to be the low translocation from silique to seed rather than a low remobilization of $\mathrm{Se}$ from senescing leaves.

Nitrogen nutrition is critical in terms of the efficiency $\mathrm{Zn}$ and Fe uptake and their allocation to seeds (Kutman et al. 2011). Our results indicate that foliar $\mathrm{N}$ application can similarly increase the relatively poor level of Se translocation from leaves to seeds. Based on their greenhouse experiments, Govasmark et al. (2008) suggested that a split application of $\mathrm{N}$ and Se could raise the contents of both $\mathrm{N}$ and $\mathrm{Se}$ in wheat grains. At stem elongation and heading stages, the split application of Se elevated its content in the seeds more than did earlier application. This outcome indicates that the translocation of Se from senescing leaves was poor.

In wheat, $\mathrm{Se}$ is substituted for $\mathrm{S}$ in methionine and cysteine residues of storage proteins such as glutenin and gamma-gliadin (Bianga et al. 2013) that represent 
Table 5 Selenium uptake $\left(\mu \mathrm{g} \mathrm{m}^{-2}\right)$ in various parts of oilseed rape and wheat plants supplied with increasing amounts of Se and harvested in 2012

\begin{tabular}{|c|c|c|c|c|c|c|c|}
\hline \multirow[t]{2}{*}{ Species } & \multirow{2}{*}{$\begin{array}{l}\text { Second N } \\
\text { application } \\
\left(\mathrm{kg} \mathrm{ha}^{-1}\right)\end{array}$} & \multirow{2}{*}{$\begin{array}{l}\text { Se application } \\
\left(\mathrm{g} \mathrm{ha}^{-1}\right)\end{array}$} & \multicolumn{5}{|c|}{ Se uptake $\left(\mu \mathrm{g} \mathrm{m}^{-2}\right)$} \\
\hline & & & Root & Stem & Senescing Leaves & Seed & Siliques/chaff \\
\hline \multirow[t]{6}{*}{ Oilseed rape } & \multirow[t]{3}{*}{0} & 0 & $1.3^{\mathrm{c}}(0.09)$ & $0.0^{\mathrm{d}}(0.00)$ & $*$ & $7.2^{\mathrm{e}}(0.51)$ & $5.8^{\mathrm{c}}(0.40)$ \\
\hline & & 7.22 & $3.3^{\mathrm{bc}}(0.10)$ & $1.6^{\mathrm{d}}(0.03)$ & $*$ & $25.1^{\mathrm{de}}(0.64)$ & $8.9^{\mathrm{c}}(0.23)$ \\
\hline & & 25 & $9.0^{\mathrm{ab}}(0.07)$ & $31.9^{\mathrm{abc}}(0.26)$ & $*$ & $55.2^{\mathrm{cd}}(0.46)$ & $24.6^{\mathrm{b}}(0.21)$ \\
\hline & \multirow[t]{3}{*}{20} & 0 & $1.5^{\mathrm{c}}(0.08)$ & $0.0^{\mathrm{d}}(0.00)$ & $*$ & $11.7^{\mathrm{de}}(0.61)$ & $6.0^{\mathrm{c}}(0.31)$ \\
\hline & & 7.22 & $2.2^{\mathrm{c}}(0.06)$ & $9.5^{\mathrm{cd}}(0.25)$ & $*$ & $16.2^{\mathrm{de}}(0.42)$ & $9.8^{\mathrm{c}}(0.27)$ \\
\hline & & 25 & $13.9^{\mathrm{a}}(0.08)$ & $43.7^{\mathrm{a}}(0.24)$ & $*$ & $89.2^{\mathrm{bc}}(0.48)$ & $37.3^{\mathrm{a}}(0.20)$ \\
\hline \multirow[t]{6}{*}{ Wheat } & \multirow[t]{3}{*}{0} & 0 & $1.1^{\mathrm{c}}(0.04)$ & $0.0^{\mathrm{d}}(0.00)$ & $1.9^{\mathrm{b}}(0.06)$ & $22.1^{\text {de }}(0.73)$ & $5.1^{\mathrm{c}}(0.17)$ \\
\hline & & 7.22 & $5.4^{\mathrm{bc}}(0.09)$ & $10.5^{\text {bcd }}(0.18)$ & $2.7^{\mathrm{b}}(0.05)$ & $32.0^{\text {de }}(0.55)$ & $7.7^{\mathrm{c}}(0.13)$ \\
\hline & & 25 & $11.8^{\mathrm{a}}(0.06)$ & $34.8^{\mathrm{ab}}(0.16)$ & $10.3^{\mathrm{a}}(0.03)$ & $129.7^{\mathrm{ab}}(0.62)$ & $28.9^{\mathrm{ab}}(0.13)$ \\
\hline & \multirow[t]{3}{*}{20} & 0 & $1.4^{\mathrm{c}}(0.04)$ & $0.0^{\mathrm{d}}(0.00)$ & $3.1^{\mathrm{b}}(0.11)$ & $20.3^{\text {de }}(0.66)$ & $6.1^{\mathrm{c}}(0.19)$ \\
\hline & & 7.22 & $4.4^{\mathrm{bc}}(0.07)$ & $11.5^{\text {bcd }}(0.17)$ & $3.0^{\mathrm{b}}(0.05)$ & $39.5^{\mathrm{de}}(0.58)$ & $8.7^{\mathrm{c}}(0.13)$ \\
\hline & & 25 & $5.0^{\mathrm{bc}}(0.02)$ & $34.4^{\mathrm{ab}}(0.15)$ & $10.9^{\mathrm{a}}(0.04)$ & $155.7^{\mathrm{a}}(0.69)$ & $22.0^{\mathrm{b}}(0.10)$ \\
\hline SE & & & 1.7 & 6.8 & 1.6 & 12.9 & 3.4 \\
\hline
\end{tabular}

An additional foliar application of $20 \mathrm{~kg} \mathrm{~N} \mathrm{ha}^{-1}$ was given to oilseed rape and wheat plants at rosette and bolting stages, respectively. Numbers within brackets show the proportion of accumulated Se in each part

Data are means, $n=3$. Values in each column followed by the same letter are not significantly different at $P \leq 0.05$ by Tukey's HSD test

*no samples for measurement

$80 \%$ of the protein in wheat grains. They provide a large pool of proteins for Se incorporation, so the Se sink in seeds is in theory large. It is known that transporters such as yellow stripe 1-like (YSL) are important for the seed loading of $\mathrm{Zn}$ and $\mathrm{Fe}$ (Palmgren et al. 2008), but similar studies on Se loading to seeds have not come to light. As the effect of foliar $\mathrm{N}$ application on SeUE or SeFR is small, other methods such as breeding are required to improve the $\mathrm{Se}$ translocation to seeds. In contrast to $\mathrm{Zn}$, there is no reported genetic variation in SeUPE or SeFR in wheat germplasm, which restricts the success of conventional breeding methods for this trait.

In perennial grasses, SeUPE and SeFR were significantly higher than in wheat or oilseed rape, especially in the first harvest. The higher root biomass and density in perennial grasses than in annual crops (Postma et al. 2014), explain the correlation between their micronutrient uptake and root properties being better than in the annual crops (Wang et al. 2006; Paez-Garcia et al. 2015). This can partly explain some of the differences recorded between the plant species. Furthermore, the seasonal growth patterns of perennial grasses affect nutrient uptake: the development of above- and below-ground plant parts is enhanced in spring, whereas the growth in mid-summer is slower (Evans 1996). The activity of roots is dependent on the assimilate supply from the canopy. Harvesting results in a loss of active roots (Evans 1996) and this probably contributes to the lower SeUPE of the second harvest.

The efficiency of Se biofortification depends significantly on seasonal weather conditions. In 2012 when the accumulation of temperature sum was slow and overall precipitation high, a higher Se dosage was required to obtain an adequate concentration in grain or seed. During the growing season, changes in temperature and rainfall result in fluctuations in soil moisture and $\mathrm{pH}$ (Cubadda et al. 2010). They, in turn, influence the speciation and bioavailability of Se in soil. In wet conditions, selenate (Se VI) is easily reduced to selenite (Se IV) that will be strongly adsorbed onto the surfaces of poorly crystalline (oxy) hydroxides of aluminum $(\mathrm{Al})$ or iron $(\mathrm{Fe})$ by means of ligand exchange (Hartikainen 2005). Hence, there is less of bioavailable form of Se for uptake across the root plasma membrane (Cubadda et al. 2010). 
Table 6 Se uptake efficiency (UPE, \%) and Se fertilizer recovery (FR, \%) of oilseed rape and wheat with or without Se fertilizer $\left(\mathrm{g} \mathrm{ha}^{-1}\right)$

\begin{tabular}{|c|c|c|c|c|c|c|}
\hline \multirow[t]{2}{*}{ Species } & \multirow[t]{2}{*}{$\mathrm{N}$ application } & \multirow[t]{2}{*}{ Se application $\left(\mathrm{g} \mathrm{ha}^{-1}\right)$} & \multicolumn{2}{|l|}{2011} & \multicolumn{2}{|l|}{2012} \\
\hline & & & UPE, \% & $\mathrm{FR}, \%$ & UPE, \% & $\mathrm{FR}, \%$ \\
\hline \multirow[t]{4}{*}{ Oilseed rape } & \multirow[t]{2}{*}{0} & 7.22 & $32^{\mathrm{a}}$ & $11^{\mathrm{a}}$ & $3.4^{\mathrm{ab}}$ & $2.5^{\mathrm{abc}}$ \\
\hline & & 25 & $45^{\mathrm{a}}$ & $14^{\mathrm{a}}$ & $4.3^{\mathrm{ab}}$ & $1.9^{\mathrm{bc}}$ \\
\hline & \multirow[t]{2}{*}{20} & 7.22 & n.d. & n.d. & $2.6^{\mathrm{b}}$ & $0.6^{\mathrm{c}}$ \\
\hline & & 25 & n.d. & n.d. & $6.6^{\mathrm{ab}}$ & $2.9^{\mathrm{abc}}$ \\
\hline \multirow[t]{5}{*}{ Wheat } & \multirow[t]{2}{*}{0} & 7.22 & $30^{\mathrm{a}}$ & $12^{\mathrm{a}}$ & $3.9^{\mathrm{ab}}$ & $1.1^{\mathrm{bc}}$ \\
\hline & & 25 & $29^{\mathrm{a}}$ & $16^{\mathrm{a}}$ & $7.4^{\mathrm{a}}$ & $4.3^{\mathrm{ab}}$ \\
\hline & \multirow[t]{2}{*}{20} & 7.22 & n.d. & n.d. & $5.0^{\mathrm{ab}}$ & $2.7^{\mathrm{abc}}$ \\
\hline & & 25 & n.d. & n.d & $7.9^{\mathrm{a}}$ & $5.4^{\mathrm{a}}$ \\
\hline & SE & 7 & 4 & 1.3 & 0.9 & \\
\hline
\end{tabular}

In 2012, a foliar application of $20 \mathrm{~kg} \mathrm{~N} \mathrm{ha}^{-1}$ was given to the plants at rosette and booting stage, respectively

Data are mean $\pm \mathrm{SE}, n=3$. Values in each column followed by the same letter are not significantly different at $P \leq 0.05$ by Tukey's HSD test. n.d, this treatment combination was not tested

Table 7 Se uptake efficiency (UPE, \%) and Se fertilizer recovery (FR, \%) of herbage biomass (timothy and red clover) at I and II harvests with or without Se fertilizer $\left(\mathrm{g} \mathrm{ha}^{-1}\right)$

\begin{tabular}{llll}
\hline Harvest & Se application $\left(\mathrm{g} \mathrm{ha}^{-1}\right)$ & UPE, \% & FR, \% \\
\hline I (15 June 2012) & 5.55 & $64^{\mathrm{a}}$ & $62^{\mathrm{a}}$ \\
& 19.25 & $54^{\mathrm{a}}$ & $54^{\mathrm{a}}$ \\
II (16 August 2012) & 5.55 & $21^{\mathrm{b}}$ & $19^{\mathrm{b}}$ \\
& 19.25 & $16^{\mathrm{b}}$ & 6.4 \\
& SE & 6.2 & $15^{\mathrm{b}}$
\end{tabular}

Data are means, $\mathrm{n}=3$. Values in each column followed by the same letter are not significantly different at $P \leq 0.05$ by Tukey's HSD test

In the present experiment with wheat or oilseed rape, the low SeFR revealed that $<10 \%$ of applied Se might be transferred to the food chain. Annual Se fertilization is required, which raises the question of the fate of Se in field ecosystem. Our results indicate that after 20 years' application of selenate (4.2-11.2 g Se ha $\left.{ }^{-1}\right)$ together with a high $\mathrm{N}$ dosage $\left(160 \mathrm{~kg} \mathrm{ha}^{-1}\right)$, the Se concentration in the organic fraction of topsoil slightly increased. However, no change was observed at the recommended $\mathrm{N}\left(80 \mathrm{~kg} \mathrm{ha}^{-1}\right)$ and Se level (2.1-5.6 $\left.\mathrm{g} \mathrm{ha}^{-1}\right)$. Moreover, no changes in the $\mathrm{Se}$ concentrations were recorded in the sub-soil samples, indicating that its leaching was not detectable.

The results show that the used analytical methods were sensitive enough to monitor small changes in the organic Se pool of soil. Nevertheless, when calculated in relation to the mass of topsoil, the increase was $0.006 \mathrm{ppm}$ in 20 years. The same extraction and analysis methods were used in a greenhouse experiment where very high addition of selenate increased the inorganic Se pool of soil (Ebrahimi et al. 2018). Approximately half of the Se fertilizer that has been absorbed by the crop plants is returned with the organic residues into the soil after harvest. The small increase in organic Se pool in our study is in line with earlier results by Yläranta (1985) and Keskinen et al. (2011).

How does Se cycle in a field ecosystem? Our estimation was based on the results of this experiment with oilseed rape as well as on the level of Se volatilization from plants and microbial activity reported in the review by Winkel et al. (2015) 
Fig. 3 Inorganic and organic Se pools in soil $\left(\mu \mathrm{g} \mathrm{kg}^{-1}\right)$ after harvesting of oilseed rape plants in a 2011 and b 2012 and $\mathbf{c}$ in topsoil $(0.00-0.05 \mathrm{~m})$ and subsoil $(0.30 \mathrm{~m})$ of a field fertilized with Se for 20 years. c Presents means of 2-3 replications (a) 2011

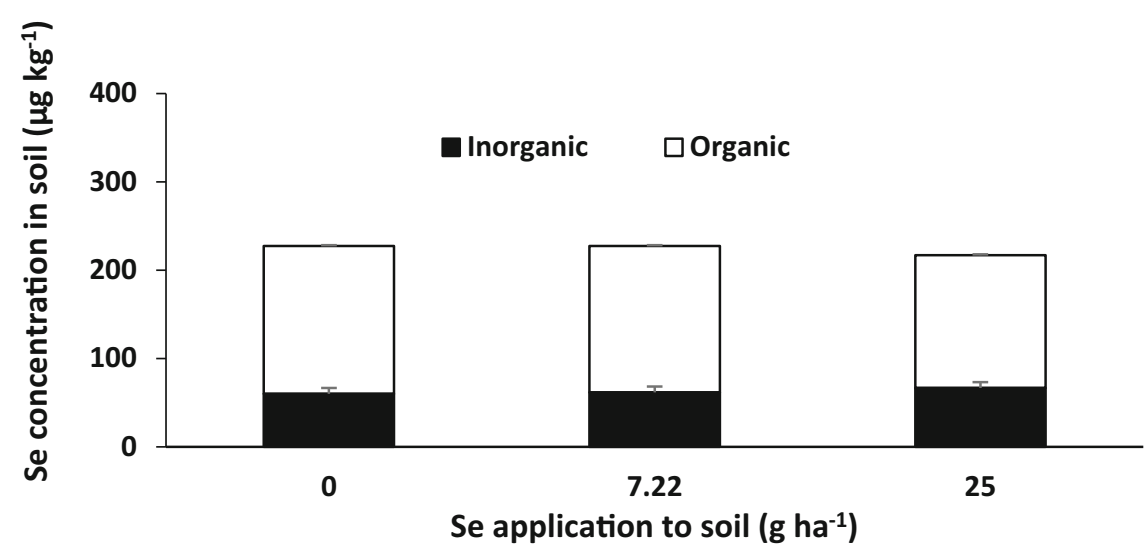

(b) $2012 \quad \square$ Inorganic $\square$ Organic

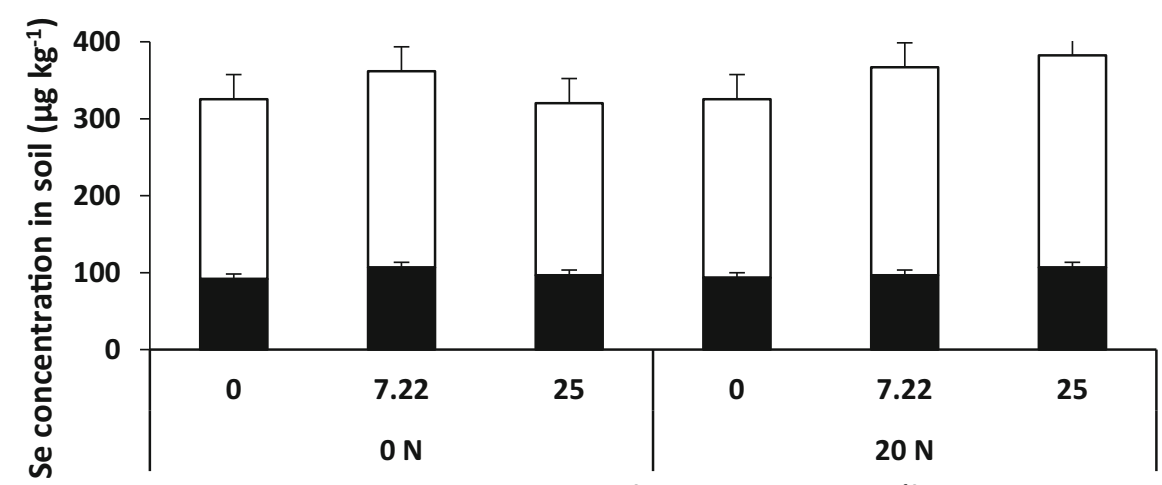

Se application to soil $\left(0,7.2\right.$ and $\left.25 \mathrm{~g} \mathrm{ha}^{-1}\right)$ and $\mathrm{N}$ application to leaves ( 0 and $20 \mathrm{~kg} \mathrm{ha}^{-1}$ )

(c) 2012

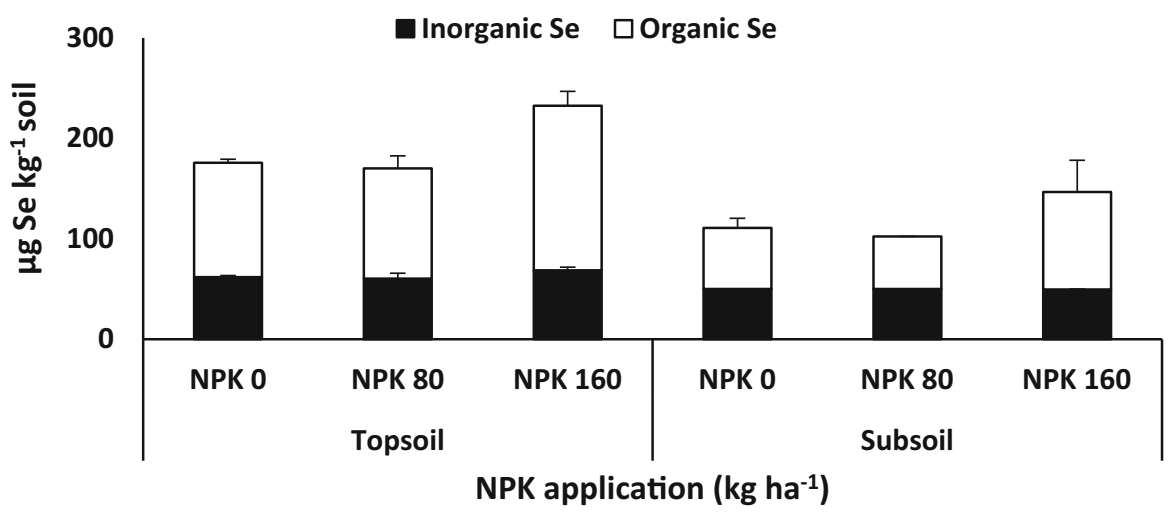

(Fig. 4). Of the fertilizer Se, oilseed rape took up $32-45 \%$ in 2011 and only $2-7 \%$ in 2012 and, consequently, $40-65 \%$ (2011) to $78-93 \%$ (2012) was left in the soil. The amount of residual fertilizer Se was determined as the difference between the amount of Se added and that taken up by plants plus the estimated amount of volatilized Se. This approach was used because no fertilization-induced changes in the inorganic and organic Se were recorded in soils. The amount of added Se to a large mass of topsoil 
Fig. 4 Schematic representation of Se cycling in the field ecosystem based on our data from oilseed rape and Winkel et al. (2015) for proportion of volatilization

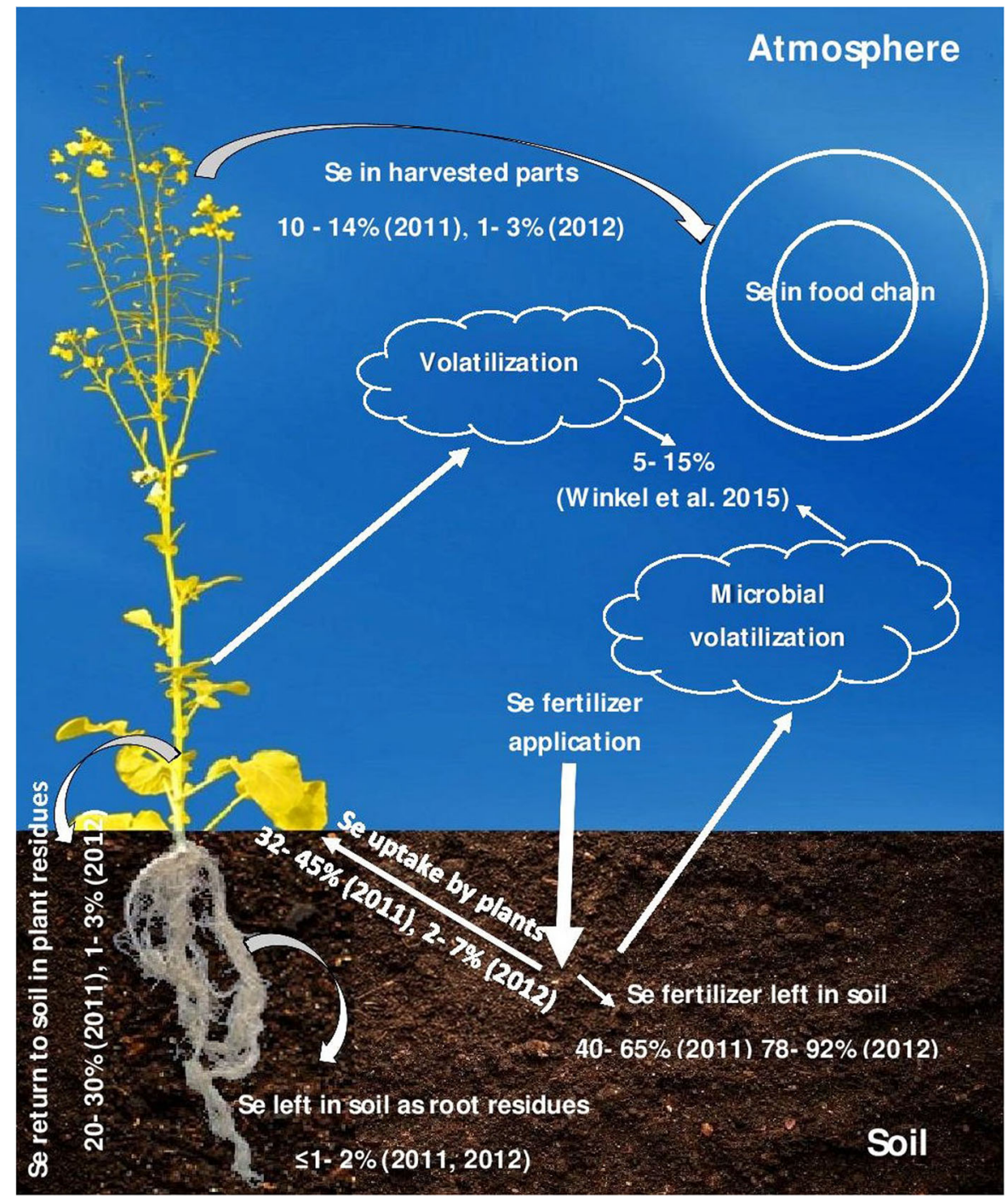

$\left(200,000 \mathrm{~kg} \mathrm{ha}^{-1}\right)$ was extremely low. The seed yield removed 10-14\% of applied Se in 2011 and only $1-3 \%$ in 2012 , the rest of Se potentially remained in the soil as root residues. Less than $2 \%$ of Se was potentially remained in soil as roots residues towards the end of growing period. The Se volatilization from plants and soil microbes is estimated to be $5-15 \%$ (Winkel et al. 2015).

\section{Conclusion}

The efficiency of fertilizer Se to elevate its content in crops depended on the plant species, environmental conditions (especially weather during the growing season) and nitrogen $(\mathrm{N})$ fertilization of the soil. The forage crops characterized by root systems of high surface area took up and accumulated $\mathrm{Se}$ more efficiently in their shoots that did the grain crops. In the second experimental year, higher rainfall may have altered soil $\mathrm{pH}$ and $\mathrm{Se}$ adsorption onto soil particles, the Se uptake by crops being only oneseventh of that in the previous year. The foliar $\mathrm{N}$ application significantly promoted the Se accumulation in the seeds of wheat and oilseed rape. Based on short- and long-term (20 years) analysis of the inorganic and organic Se pools in soils, it can be concluded 
that at the recommended level of Se application no accumulation can be expected.

Acknowledgements Open access funding provided by University of Helsinki including Helsinki University Central Hospital. The Aino and August Tiura Foundation, Maj and Tor Nessling Foundation (Grant No. 0000), Niemi Foundation, and Yara Suomi Ltd. are acknowledged for their financial support in Finland.

Open Access This article is distributed under the terms of the Creative Commons Attribution 4.0 International License (http:// creativecommons.org/licenses/by/4.0/), which permits unrestricted use, distribution, and reproduction in any medium, provided you give appropriate credit to the original author(s) and the source, provide a link to the Creative Commons license, and indicate if changes were made.

\section{References}

Alfthan G, Eurola M, Ekholm P, Venäläinen ER, Root T, Korkalainen K, Hartikainen H, Salminene P, Hietaniemi V, Aspila P, Aro A (2015) Effects of nationwide addition of selenium to fertilizers on foods, and animal and human health in Finland: from deficiency to optimal selenium status of the population. J Trace Elem Med Biol 31:142-147

Avice JC, Etienne P (2014) Leaf senescence and nitrogen remobilization efficiency in oilseed rape (Brassica napus L.). J Exp Bot 65:3813-3824

Banuelos GS, Terry N, Leduc DL, Pilon-Smits EAH, Mackey B (2005) Field trial of transgenic Indian mustard plants shows enhanced phytoremediation of selenium-contaminated sediment. Environ Sci Technol 39:1771-1777

Bañuelos GS, LeDuc DL, Pilon-Smits EAH, Tagmount A, Terry N (2007) Transgenic Indian mustard overexpressing selenocysteine lyase or selenocysteine methyltransferase exhibit enhanced potential for selenium phytoremediation under field conditions. Environ Sci Technol 41:599-605

Berkelaar E, Hale B (2000) The relationship between root morphology and cadmium accumulation in seedlings of two durum wheat cultivars. Can J Bot 78:381-387

Bianga J, Govasmark E, Szpunar J (2013) Characterization of selenium incorporation into wheat proteins by two-dimensional gel electrophoresis-laser ablation ICP MS followed by capillary HPLC-ICP MS and electrospray linear trap quadrupole orbitrap MS. Anal Chem 85:2037-2043

Broadley MR, White PJ, Bryson RJ, Meacham MC, Bowen HC, Johnson SE et al (2006) Biofortification of UK food crops with selenium. Proc Nutr Soc 65:169-181

Broadley MR, Alcock J, Alford J, Cartwright P, FairweatherTait SJ, Foot I, Hart DJ, Hurst R, Knott P, McGrath SP, Meacham MC, Norman K, Mowat H, Scott P, Stroud JL, Tovey M, Tucker M, White PJ, Young SD, Zhao FJ (2010) Selenium biofortification of high-yielding winter wheat (Triticum aestivum L.) by liquid or granular Se fertilisation. Plant Soil 332:5-18
Brown KM, Arthur JR (2001) Selenium, selenoproteins and human health: a review. Public Health Nutr 4(2B):593-599

Cubadda F, Aureli F, Ciardullo S, D'Amato M, Raggi A, Raghunath Acharya Reddy RAV, Prakash NT (2010) Changes in selenium speciation associated with increasing tissue concentrations of selenium in wheat grain. J Agric Food Chem 58:2295-2301

Ebrahimi N, Hartikainen H, Simojoki A, Hajiboland R, Seppänen MM (2015) Dynamics of dry matter and selenium accumulation in oilseed rape (Brassica napus L.) in response to organic and inorganic selenium treatments. Agric Food Sci 24:104-117

Ebrahimi N, Hartikainen H, Hajiboland R, Seppänen MM (2018) Uptake and remobilization of selenium in Brassica napus L. plants supplied with selenate or selenium-enriched plant residues. J Plant Nutr Soil Sci. https://doi.org/ 10.1002/jpln.201700316 (in press)

Eich-Greatorex S, Sogn TA, Falk-Øgaard A, Aasen I (2007) Plant availability of inorganic and organic selenium fertiliser as influenced by soil organic matter and $\mathrm{pH}$. Nutr Cycl Agroecosyst 79:221-231

Eurola M, Ekholm P, Ylinen M, Kovistoinen P, Varo P (1990) Effects of selenium fertilization on the selenium content of cereals grains, flour, and bread production in Finland. Cereal Chem 67:334-337

Eurola M, Afthan G, Ekholm P, Levonmäki M, Root T, Venäläinen ER, Ylivainio K (2008) Seleenityöryhmän raportti 2008 (Results of Finnish selenium monitoring program). Maa ja Elintarviketalous 132 (In Finnish with English abstract). MTT Agrifood Research Finland, Jokioinen, Finland. http://www.mtt.fi/met/pdf/met132.pdf

Evan LT (1996) Crop evolution, adaptation and yield. Cambridge University Press, London, 500 pp. ISBN-13: 978-0521295581; ISBN-10: 0521295580

Fordyce FM (2013) Selenium deficiency and toxicity in the environment. In: Selinus O (ed) Essentials of medical geology. Springer, Dordrecht, pp 373-415

Frankenberger WT, Karlson U (1994) Soil management factors affecting volatilization of selenium from dewatered sediments. Geomicrobiol J 12:265-278

Frankenberger WT, Karlson U (1995) Volatilization of selenium from a dewatered seleniferous sediment: a field study. $\mathrm{J}$ Ind Microbiol 14:226-232

Govasmark E, Singh BR, MacLeod JA, Grimmett MG (2008) Selenium concentration in spring wheat and leaching water as influenced by application times of selenium and nitrogen. J Plant Nutr 31:193-203

Gupta UC, Gupta SC (2000) Selenium in soils and crops, its deficiencies in livestock and humans: implications for management. Commun Soil Sci Plant Anal 31:1791-1807

Gupta UC, Gupta SC (2002) Quality of animal and human life as affected by selenium management of soils and crops. Commun Soil Sci Plant Anal 33:15-18

Gupta UC, McRae KB, Winter KA (1982) Effect of applied selenium on the selenium content of barley and forages and soil selenium depletion rates. Can J Soil Sci 62:145-154

Harskamp JG, O’Donnell MJ, Berkelaar E (2010) Determining the fluxes of $\mathrm{Tl}^{+}$and $\mathrm{K}^{+}$at the root surface of wheat and canola using $\mathrm{Tl}(\mathrm{I})$ and $\mathrm{K}$ ion-selective microelectrodes. Plant Soil 335:299-310 
Hartikainen H (2005) Biogeochemistry of selenium and its impact on food chain quality and human health. J Trace Elem Med Biol 18:309-318

Keskinen R (2012) Selenium fertilization: plant uptake and residuals in soil. Doctoral thesis. MTT Agrifood Research Finland, ISSN 1798-1840. http://www.mtt.fi/mtttiede/pdf/ mtttiede20.pdf

Keskinen R, Turakainen M, Hartikainen H (2010) Plant availability of soil selenate additions and selenium distribution within wheat and ryegrass. Plant Soil 333:301-313

Keskinen R, Räty M, Yli-Halla M (2011) Selenium fractions in selenate-fertilized field soils of Finland. Nutr Cycl Agroecosyst 91:17-29

Keskinen R, Yli-Halla M, Hartikainen H (2013) Retention and uptake by plants of added selenium in peat soils. Commun Soil Sci Plant Anal 44:3465-3482

Klikocka H, Kobiałka A, Szostak B, Barczak B (2017) Effect of sulphur and nitrogen fertilization on the selenium content and uptake by grain of spring wheat. $\mathrm{J}$ Elementol 22:985-994

Kutman UB, Yildiz B, Cakmak I (2011) Effect of nitrogen on uptake, remobilization and partitioning of zinc and iron throughout the development of durum wheat. Plant Soil 342:149-164

Lee J, Masters DG, White CL, Grace ND, Judson GJ (1999) Current issues in trace element nutrition of grazing livestock in Australia and New Zealand. Aust J Agric Res 50:1341-1364

Li S, Bañuelos GS, Min J, Shi W (2015) Effect of continuous application of inorganic nitrogen fertilizer on selenium concentration in vegetables grown in the Taihu Lake region of China. Plant Soil 393:351-360

Lin ZQ, Hansen D, Zayed A, Terry N (1999) Biological selenium volatilization: method of measurement under field conditions. J Environ Qual 28:309-315

Paez-Garcia A, Motes CM, Scheible WR, Chen R, Blancaflor EB, Monteros MJ (2015) Root traits and phenotyping strategies for plant improvement. Plants 4:334-355

Palmgren MG, Clemens S, Williams LE, Krämer U, Borg S, Schjørring JK, Sanders D (2008) Zinc biofortification of cereals: problems and solutions. Trends Plant Sci 14(9):464-473. https://doi.org/10.1016/j.tplants.2008.06. 005

Postma JA, Schurr U, Fiorani F (2014) Limiting nutrient availability: linking physiological models and experimentation. Biotechnol Adv 32(1):53-65

Rayman MP (2002) The argument for increasing the selenium intake. Proc Nutr Soc 61:203-215

Ros GH, van Rotterdam AMD, Bussink DW, Bindraban PS (2016) Selenium fertilization strategies for bio-fortification of food: an agro-ecosystem approach. Plant Soil 404:99-112

Sillanpää M, Jansson H (1992) Status of cadmium, lead, cobalt and selenium in soils and plants of thirty countries, vol 65 . FAO Soil Bulletin. FAO, Quebec City, p 195

Stavridou E, Young SD, Thorup-Kristensen K (2012) The effect of catch crop species on selenium availability for succeeding crops. Plant Soil 351:149-160

Stroud JL, Broadley MR, Foot I, Fairweather-Tait SJ, Hart DJ, Hurst R, Knott P, Mowat H, Norman K, Scott P, Tucker M, White PJ, McGrath SP, Zhao FJ (2010) Soil factors affecting selenium concentration in wheat grain and the fate and speciation of Se fertilisers applied to soil. Plant Soil 332:19-30

Terry N, Zayed AM, de Souza MP, Tarun AS (2000) Selenium in higher plants. Ann Rev Plant Physiol Plant Mol Biol 51:401-432

Wang H, Inukai Y, Yamauchi A (2006) Root development and nutrient uptake. Crit Rev Plant Sci 25:279-301

Whelan BR (1989) Uptake of selenite fertilizer by subterranean clover pasture in Western Australia. Aust J Exp Agric 29:517-522

Wichtel JJ (1998) A review of selenium deficiency in grazing ruminants. Part 1: new roles for selenium in ruminant metabolism. N Z Vet J 46:47-52

Winkel LHE, Vriens B, Jones GD, Schneider LS, Pilon-Smits E, Bañuelos GS (2015) Selenium cycling across soil-plantatmosphere interfaces: a critical review. Nutrients 7:4199-4239

Yassen AA, Adam SM, Zaghloul SM (2011) Impact of nitrogen fertilizer and foliar spray of selenium on growth, yield and chemical constituents of potato plants. Aust J Basic Appl Sci 5:1296-1303

Yläranta T (1983a) Selenium in Finnish agricultural soil. Ann Agric Fenn 22:29-39

Yläranta T (1983b) Sorption of selenite and selenite in the soil. Ann Agric Fenn 22:122-136

Yläranta T (1984) Effect of selenite and selenate fertilization and foliar spraying on selenium content of timothy grass. Ann Agric Fenn 23:96-108

Yläranta T (1985) Increasing the selenium content of cereal and grass crops in Finland. Ph.D. thesis, University of Helsinki, Yliopistopaino, Finland

Zayed AM, Terry N (1994) Selenium volatilization in roots and shoots: effect of shoot removal and sulfate level. J Plant Physiol 143:8-14

Publisher's Note Springer Nature remains neutral with regard to jurisdictional claims in published maps and institutional affiliations. 